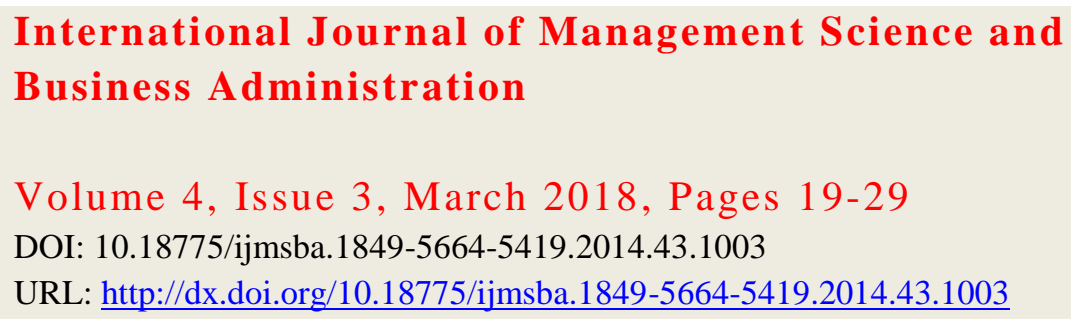

\title{
Analysis of Top Management Support and Individual Factors Influence on Accounting Information System and Its Impact on the Accounting Information Quality for Projects
}

\author{
${ }^{1}$ Victoria Lucas Mkonya, ${ }^{2}$ Yu Jintian, ${ }^{3}$ Stella Binauli Nanthuru, ${ }^{4}$ Salimu Abushiri Jinyevu \\ ${ }^{1,2,3,4}$ School of Management, Wuhan University of Technology, Wuhan, P. R. China
}

\begin{abstract}
The development of information technology in accounting has assisted on accountability and transparency of projects funds through the use of accounting information system for projects in producing quality reports. Top management support and individual factor are considered to have a high impact on accounting information system implementation. The study examined the effect of top management support and individual factors on the implementation of accounting information system and its impact on accounting information quality for projects in Tanzania. The study was carried out on nongovernmental organizations operated in Tanzania in different sectors. A questionnaire used to collect information from users of accounting information and accounting information system in different nongovernmental organizations projects in Tanzania. The results indicate that top management support and individual factors significantly influence accounting information system. Furthermore, it was found that the accounting information quality is influenced considerably by accounting information system.
\end{abstract}

Keywords: Top management support, Individual factors, Accounting information quality, Accounting information systems, Projects

\section{Introduction}

Accountability and control for efficiency/cost-effectiveness have turned out to be the main challenge in various projects where funds are channeled. Projects sustainability has been noted as a serious problem, and there is little information concerning the sustainability of projects rather than how they were implemented (Bamberger and Cheema, 1990). Attention has been increased to ensure that nongovernmental organization projects both national and international are accountable for the funds received and spent to all stakeholders of the organization to assist them in managing the resources (avoidance of fraud) and for decision making. Development partners are the main funders of nongovernmental organizations projects. Nongovernmental organizations leaders have highlighted development partners' expectations and financial accounting as central to their current accountability practices (Schmitz et al., 2012). For achievement of effectiveness in facilitating monitoring programs and projects, accountability has been viewed as a fundamental (O'Dwyer and Unerman, 2010). Nongovernmental organizations accountability is very strong to funders in the form of reports and evaluations. The funding agency required projects to produce periodic financial reports for the funds they raise and spend as a means of accountability and decision making.

Sophisticated systems have been developed to monitor projects implementation and compare intended and actual physical performance (Bamberger and Cheema, 1990). Accounting records are now transported from paperwork to sophisticated accounting information systems which collect, records, store and process data to produce information. The wide use of the system in producing quality information assists the information users to be productive through the improvement of decision making in projects. Management, investors, lenders, and other creditors need accounting information as means of communication in projects and assists in decision making. Ika and Lytvynov (2011) revealed that the use of financial reports for a project in making decision "managing for result" is a method of achieving a better result for a sustainable project. Poor information quality contributes to worse decision making (Elonen and Artto, 2003). Accounting information quality for projects is achieved from the application of accounting information system (Ilhemeje, 2015) but projects 
stakeholders' lack of systematic information on how their investments are producing the intended benefits by the use of accounting information system (Bamberger and Cheema, 1990).

The sustainable success in project management is closely linked with information system and information technology (Hartman and Ashrafi, 2002). Most of the nongovernmental organization projects use standard office tools to manage a huge amount of field data. Word processor and spreadsheet have been used in running data. Data in spreadsheet remain with a specific individual and found easier to collude in any circumstances. The nongovernmental organizations still fail to utilize the benefit of accounting information system whereby different information is scattered on a piece of paper and computer with different people. It was revealed by Al-Ammary and Hamad (2012) that nongovernmental organization projects hold basic information technology and limited software essential to perform the intended task and the ones who use advanced technology faced a problem with the adopted technology on matching with the organization missions and objectives. Most of the software problems which hinder the performance of the projects revealed to relate to management, organizational, human and cultural issues (Hartman and Ashrafi, 2002).

The implementation of accounting information system requires the support of top management and individual factors (Komala, 2012); Iskandar, 2015). They are important factors in the formulation of organizational goals and determining the success and failure of the implementation of the accounting information systems. Hence the study examines the effect of top management support and individual factors on the implementation of accounting information system and its impact on quality of accounting information for nongovernmental organization projects in Tanzania. The paper proceeds as follows: part two discusses literature review which covers basic, and theories for the study, part three research models and hypothesis development, part four research methodology part five result and discussion, and the last part draw some conclusion on the study.

\section{Review of Relevant Literature}

\subsection{Theoretical Framework}

\subsubsection{Contingency Theory}

Contingency theory has been adopted to explain the contingent factors that influence the implementation of accounting information system for nongovernmental organization projects in Tanzania. Information system research applies contingency theory to explain contingency variables that interrelate on implementing an effective information system (Reinking, 2012). The theory has also been developed in accounting information system and management information system studies. Contingency variables are used in systems development and systems implementation. It has been found that contingency theory in the implementation of accounting information system is closely linked with the specific attribute of organizational and individual variables (Ginzberg, 1980). These variables interconnect to each other to produce successful system implementation. Various researchers have identified organization characteristics as organization structure, top management support (Chenhall and Morris, 1986; Mahmood and Swanberg, 2001; Daoud and Triki 2013), and individual characteristics as individual educational level, user competency , user knowledge, training, professional level and skills level (Mahmood and Swanberg, 2001; Daoud and Triki, 2013).

Contingency theory has been criticized by different researchers as Otley (1980), who recognized that system designed as weak when the effectiveness of the organization in design and implementation of information system are predicted and interrelated with contingency variable of technology, environment, and organizational form while is noted that contingency theory strongly meets the criteria considered by science (increasing knowledge) and weak in technology (Betts, 2003). Moreover, contingency variables considerably vary, relating to the study due to the unclear definition of variables; therefore, different environment needs different variables to ensure net benefits of contingency theory (Reinking, 2012). This study will examine the influence of contingency factor top management support and individual characteristics on implementation of accounting information system.

\subsubsection{Task-Technology Fit Theory}

The theory is originated from the organizational contingency theory with the assumption that there is no one way for an organization to organize and every definite technique of organizing is not equally effective (Galbraith, 1973). The employment of task-technological fit theory in information system explains how benefits from the utilization of information system are attained. Kanellis et al. (1999) identified that the use and benefits of an information system are 
achieved when the information system is well-matched to the intended activity that should be performed.

The theory of the task-technology is linked with processing procedure in the study on accounting information system for projects in the task of managing and control of project financial resources through recording, processing, and reporting financial information for projects. According to task fit theory, the information needed to be expressed to the user will depend on the information system used (Daft et al., 1987). The choice of appropriate accounting information system for project differs according to the need and want of the projects to accomplish the intended mission. Characteristics and features which are specified in the operation of the organization according to their requirement are determinants of the effectiveness of the organization (Furneaux, 2012). The task-technological fit is represented as a match between task and the competence of an information system in its operation (Junglas et al., 2008).

Task-technological fit theory has been studied on different perspective where Lippert and Forman (2006) examine technological features and fits of the requirement of the task while Wu et al., (2007) examine how information needs of the tasks are met with system functionality and service. Task technological fit is applied in the study in the act of recording, processing, and reporting accounting information for projects through the utilization of accounting information system.

\subsection{Top Management Support}

The implementation of sustainable information system necessitate right environment for system implementation and ensure proper guidance to people who are using, managing and developing the system. Top management has been recognized by prior researchers as the key actor on the implementation of the information system for projects and has an important role in the implementation of accounting information system. It has been revealed as a critical success factor (Young and Jordan 2009) and recognized as vital in formulating organization action plans to solve organizational problems, motivating changes in the organization and making decisions (Laudon and Laudon 2012). The implementation of accounting information system for projects requires allocation of resources for designing, training of staff and technical process. Top management sets organizational strategy for achieving organizations plans, and they allocate the human and financial resources to coordinate the work and achieve success (Laudon and Laudon 2012). Senior managers are the main part of the success of any activity implemented in the project (Baccarini 1999). They initiate organizational goals and ensure the plans and goals are achieved as expected. Daoud and Triki (2013) revealed that top management involvement has a positive impact on the accounting information system on investigating the effects of top management on accounting information system. Mahmood and Swanberg, (2001) found managers support have a better chance of avoiding system inefficiency and failure. Zwikael (2008) recognized the positive effect on top management support on implementation of software and projects success in examining management support process that impacts the growth of software sector. Kuen et al., (2009) identify top management support influence the project success. Regarding the function of top managers as decision makers, policy formulation, allocation of resources, supervising and review of the implementation of accounting information system for projects, their support and commitment might be associated with a greater influence on designing and execution of accounting information system and information success on the project (Young and Jordan 2009). The support of top management on policy formulation, allocation of resources and supervision on accounting information system for projects are examined

\subsection{Individual Factors}

The human factors impact on the usage of information technology and information system revealed as a continuing research question in management information system literature (Szewczak and Snodgrass, 2002). The most success factor for information systems are linked to individual factors and it has been revealed that people are vital assets in any organization (Aziz et al., 2012). Information technology and information system implementation is likewise affected by skill level, education level, training level, professional level and individual attitude toward information technology and information systems within the organization (Mahmood and Swanberg, 2001). Lack of training/skills to organization staff reported as a cause for failure in numerous information systems implementation (Tambovcevs, 2010) while lack of competent personnel to plan and implement projects and program recognized as the main course of project failure (Ika 2012). The project manager work experience reviewed as critical success factors (Hyvari, 2006). The inefficiency of accounting information system is due to lack of competency skills personnel, and absence of training to staff (Shareia, 2006) and accounting personnel competency viewed as important in the success of accounting information system (Daoud and Triki, 2013). Training for project staff is a critical success factor for project achievement (Ika et al., 2012). Moreover, accounting managers knowledge was recognized to influence accounting information system (Komala 2012). 
The level of a project staffs experience, education, skills, and knowledge are examined to measure their impact on the implementation of accounting information system.

\subsection{Accounting Information System}

Accounting information system is tools designed to assist in management and control of organization financial resources when incorporated with information technology system. Sajady H. et al., (2008) revealed that accounting information system is decisive in implementing and managing an organization internal control system. Nicolaou, (2000) defined accounting information system as a computer-based system that processes financial information which is an aid in decision making in the condition of coordination and control of organizational activities and enhances corporation within the organization. They are a subsystem of the management information system with the ability to collect data, transform available data into information and providing the information to internal and external stakeholders (McLeod and Schell, 2008; Gelinas and Dull, 2012). Also identified as a subsystem that processes financial and non-financial transactions (Hall, 2007). Accounting information system recognized as an important system of reporting which provide quality accounting information to stakeholders in making a useful decision (Shipper and Vicent, 2003). Accounting information system composes of software, hardware, procedure, database, brain-ware, telecom-networks, and procedure (Romney and Steinbart, 2012) which work together to process the financial data to become financial information which is accurate, appropriate, reliable for the management and help the organization to achieve its goal.

\subsection{Accounting Information Quality}

The information is said to be useful for decision making when it assists the project in planning and provides information which is useful in creating strategies and plans for attaining the particular goal, and it comprises of qualitative characteristics (Spiceland et al., 2011; Hall, 2011). Different techniques have been used by researchers to clarify accounting information quality. McLeod and Schell (2008) identified relevance, accurate, complete and timely as criteria for accounting information quality. Xu (2003) evaluate accounting information quality by its consistency, accuracy, completeness, and timeliness. Abdallah (2014) determined the accounting information quality in the form of its credibility, accuracy, appropriateness, timing, importance, and fulfillment while Nelson et al. (2005) included, content, timeliness, accuracy, and format, as criteria for information quality. Apart from accurate, timeliness, relevance and complete Hall (2011) added a summary as a criterion to measure the quality of accounting information. Compliance, effectiveness, integrity, efficiency, availability, confidential and truth revealed as characteristics of quality of accounting information by Susanto (2013). Also, the quality of accounting information has been recognized as comparability, consistency, relevance, understandability, reliability (faithful representation) (Kanakriyah, 2016). Quality information is generalized on its reliability form of reporting, timeliness, and relevance to decision making (Sajady 2008). Therefore, quality of information in this research is measured by accuracy, relevance, consistency, completeness, neutrality, understandability and timeliness.

\section{Study Model and Hypothesis}

The study examined the effect of top management support and individual factors on the implementation of accounting information system and its impact on accounting information quality for nongovernmental organizations projects in Tanzania. The model of the study and hypothesis were developed from existing literature reviewed. Relevant variables are top management support, individual factors, accounting information system and accounting information quality and the study hypothesis are:

H 1: The Accounting Information System is significantly influenced by individual factors

H 2: The Accounting Information System is significantly influenced by top management support

H 3: The Accounting Information Quality is significantly influenced by accounting information system 


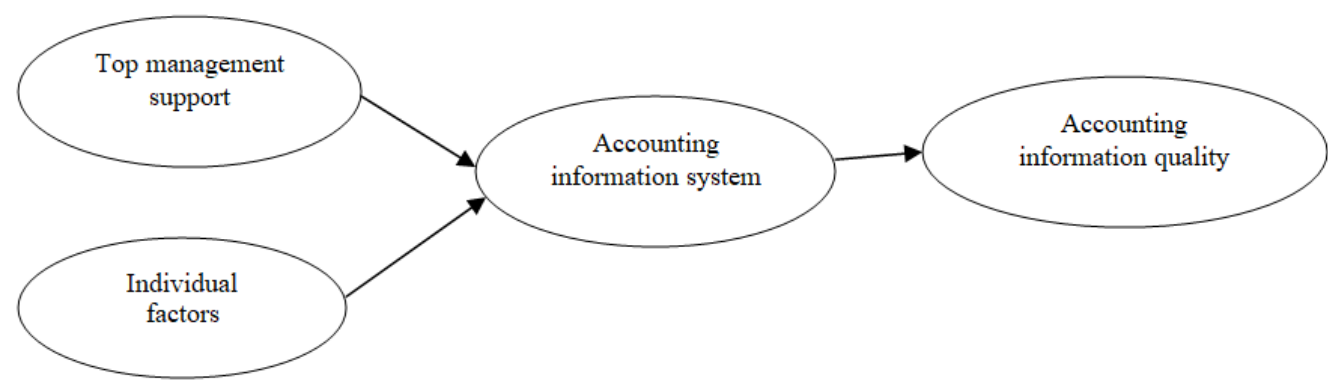

Figure1: Theoretical framework of the study

\section{Research Methodology}

The study used survey method and questionnaire as the tool for collecting information. Closed questions applied in the research as it's direct to the point and allow the use of statistical analysis (Cohen et al., 2007; Saunders et al., 2009). The questionnaire was constructed using 5-point Likert scale measurement where 1 indicates strongly disagree and 5 strongly agree. The sample comprised nongovernmental organization projects in Tanzania and a total of 200 questionnaires distributed to the accounting information users (accountants, investors, auditors, project managers, monitoring and evaluation teams) and those who use accounting information system for projects. The number of questionnaires filled and collected amounted to 103 which is $52 \%$ of all respondents. Statistical Package for the Social Sciences (SPSS) version 21 used in research to analyze quantitative data. Regression analysis was also used to explore the relationship between top management support, individual factors, accounting information system and accounting information quality.

\section{Results and Discussion}

\subsection{Reliability Test}

Reliability of variables was measured to determine stability and consistency of the scale in measuring the concepts. The most popular measure of internal consistency is Cronbach's alpha which presents the coefficient of inter-item correlation. The value of consistency is expressed as coefficient between 0 and 1, the higher the value of the coefficient, the more the consistency is. According to Hair et al., (2012) the value of Cronbach's alpha which is higher than 0.70 is suitable for internal consistency, while the value between 0.6 and 0.70 is reasonable. Moreover, Cronbach's alpha value less than 0.60 assumed lack of reliability (Nunnally and Bernstein, 1994). Table 1 present Cronbach's alpha coefficient of the constructs. The value of Cronbach's alpha of all variables is greater than 0.7 which indicate the measurement used in this research were valid and consistent.

Table 1: Reliability statistics

\begin{tabular}{|l|l|}
\hline \multicolumn{1}{|c|}{ Variables } & Cronbach's Alpha \\
\hline Top management support & .898 \\
\hline Individual factor & .907 \\
\hline Accounting information system & .897 \\
\hline Accounting information quality & .798 \\
\hline
\end{tabular}

\subsection{Validity Test}

Principal component analysis with varimax Kaizer normalization rotation method was performed to evaluate and identify the process of the vital dimension and number of components. The Keiser-Meyer-Olkin measure of sampling adequacy and Bartlett's Test of Sphericity used to examine the appropriateness of factor analysis. KMO value varies from 0 to 1 , and a value close to 1 shows that patterns of correlations are relatively compact and factor analysis is applicable while the value close to 0 shows that the sum of partial correlations is large relative to the sum of correlations, which result to diffused pattern of correlation; hence inappropriateness of factor analysis occurs. KMO value greater than 0.5 is considered to be significant (Hair et al., 1992). Furthermore, Kaiser (1970) indicate values between 0.5 and 0.7 are mediocre, values between 0.7 and 0.8 are good, values between 0.8 and 0.9 are great and superb values above 0.9 . The 
KMO value in table 2 is 0.878 which is in the range of great hence is appropriate for use in this study. Bartlett's Test of Sphericity tests the null hypothesis that the original correlation matrix is an identity matrix. Table 2 indicates Bartlett's test is highly significant $(\mathrm{p}<0.05)$, and therefore support the appropriateness of factor analysis of this study.

Table 2: KMO and Bartlett's Test

\begin{tabular}{|l|l|r|}
\hline \multicolumn{2}{|l|}{ Kaiser-Meyer-Olkin Measure of Sampling Adequacy. } & .878 \\
\hline \multirow{3}{*}{ Bartlett's Test of Sphericity } & Approx. Chi-Square & 2420.445 \\
\cline { 2 - 3 } & df & 496 \\
\cline { 2 - 3 } & Sig. & .000 \\
\hline
\end{tabular}

\subsection{Regression Analysis}

Linear Regression analysis is applied to test whether there is influence between independent variables (top management support, individual factor) and the dependent variable (accounting information system). Table 3 indicates the model summary of the relationship between top management support, individual factor and accounting information system. The value of $\mathrm{R}$ shows the correlation between the observed and predicted values (top management support and individual factor) of the dependent variable (accounting information system). The value of $\mathrm{R}$ varies from -1 to 1 and the sign specify the direction either positive or negative relationship. It is found that the value of $\mathrm{R}$ is 0.760 which is positive indicating that there is a positive correlation between top management supports, individual factor and accounting information system. This is due to the regression model selected can predict $76 \%$ of the variance accounting information system.

R2 explains the change in the dependent variable accounting information system due to independent variable top management support and individual factor. The value of R2 is 0.577 which indicates that top management support and individual factor simultaneously contribute $57.7 \%$ variation in accounting information system of nongovernmental organization projects in Tanzania and the rest can be attributed to other factors. The value of adjusted R2 reflects the goodness of fit of the model in the population and should be equal to or very close to the value of R2 (Field, 2009). The value difference of adjusted R2 and R2 in the model summary is $0.008(0.577-0.569)$ this closeness means the model has been derived from the population rather than the sample.

Table 3: Model Summary

\begin{tabular}{|c|c|c|c|c|}
\hline Model & R & R Square & $\begin{array}{c}\text { Adjusted R } \\
\text { Square }\end{array}$ & $\begin{array}{c}\text { Std. Error of the } \\
\text { Estimate }\end{array}$ \\
\hline 1 & $.760^{\mathrm{a}}$ & .577 & .569 & .57775 \\
\hline
\end{tabular}

Predictors(Constant), Individual factor, Top management support

Table 4 displays the ANOVA results which test if a model is significantly better at predicting the outcome than using mean. The F-Test for regression model is 68.220 with a significant value of $0.000(\mathrm{p}=.000<0.05)$ which shows that a model is a good fit for predicting the outcome of the variable. This follows the rule of thumb which states that the model is significant if the value of F-test is greater or equal to 2 Soyinka et al., (2017). However, Field (2009) argue that the model is significant if the value of F-test is greater than 1.

Table 4: ANOVA $^{\mathrm{a}}$

\begin{tabular}{|l|l|r|r|r|r|l|}
\hline \multicolumn{2}{|l|}{ Model } & Sum of Squares & df & Mean Square & F & Sig. \\
\hline \multirow{4}{*}{1} & Regression & 45.543 & 2 & 22.772 & 68.220 & $.000^{\mathrm{b}}$ \\
\cline { 2 - 8 } & Residual & 33.380 & 100 & .334 & & \\
\cline { 2 - 8 } & Total & 78.923 & 102 & & & \\
\hline
\end{tabular}

a. Dependent Variable: Accounting information system

b. Predictors: (Constant), Individual factor (ID), Top management support (TMS) 
Coefficient Table 5 explains the importance of independent variable top management support and individual factor in predicting dependent variable accounting information system. According to Field (2009), the value of unstandardized (B) coefficient explains the relationship between dependent variable (accounting information system) and each independent variable (top management support and individual factor). The results indicate that for every increase in top management support result to the increase in of implementation of accounting information system by 0.467 and for every increase in individual factor result to increase of implementation of accounting information system by 0.396 . The $t$ value of top management support is 6.085 at $\mathrm{p}<0.05$ and individual factor $\mathrm{t}$ value is 5.854 at $\mathrm{p}<0.05$, this means that are a significant predictor of accounting information system. From the $\mathrm{t}$-statistic values top management support found to have slightly more impact than an individual factor. Standard beta coefficient illustrates some deviations that the outcome will change as a result of a change of one standard deviation in the predictor (top management support and individual facto). Top management support standard beta coefficient is 0.450 , and an individual factor is 0.433 which means that top management support has a bit more impact on the model.

Table 5: Coefficients ${ }^{\mathrm{a}}$

\begin{tabular}{|c|c|c|c|c|c|c|}
\hline \multicolumn{2}{|c|}{ Model } & \multicolumn{2}{|c|}{ Unstandardized Coefficients } & \multirow{2}{*}{$\begin{array}{c}\text { Standardized } \\
\text { Coefficients } \\
\text { Beta }\end{array}$} & \multirow[t]{2}{*}{$\mathrm{t}$} & \multirow[t]{2}{*}{ Sig. } \\
\hline & & $\mathrm{B}$ & Std. Error & & & \\
\hline \multirow[t]{3}{*}{1} & $\begin{array}{l}\text { (Constant } \\
\text { ) }\end{array}$ & .497 & .265 & & 1.872 & .064 \\
\hline & TMS & .467 & .077 & .450 & 6.085 & .000 \\
\hline & ID & .396 & .068 & .433 & 5.854 & .000 \\
\hline
\end{tabular}

a. Dependent Variable: Accounting information system

Table 6 indicates the model summary of the relationship between accounting information system and accounting information quality. The value of $\mathrm{R}$ shows the correlation between the observed and predicted values (accounting information system) of the dependent variable (accounting information quality). The correlation between accounting information system and accounting information quality is $0.646(\mathrm{R}=0.646)$. This shows that there is a positive correlation between accounting information system and accounting information quality. This is due to the regression model selected can predict $64.6 \%$ of the variance accounting information quality. R2 explains the change in dependent variable due to the independent variable. The value of $\mathrm{R} 2$ is 0.417 which indicate that accounting information system contributes $41.7 \%$ variation in accounting information quality of nongovernmental organization projects in Tanzania and the rest can be attributed to other factors. The value difference of adjusted R2 and R2 in the model summary is $0.005(0.417-0.412)$ this closeness means the model has been derived from the population rather than the sample.

Table 6: Model Summary

\begin{tabular}{|l|r|r|r|c|}
\hline Model & R & R Square & \multicolumn{1}{|c|}{$\begin{array}{c}\text { Adjusted R } \\
\text { Square }\end{array}$} & $\begin{array}{c}\text { Std. Error of the } \\
\text { Estimate }\end{array}$ \\
\hline 1 & $.646^{\mathrm{a}}$ & .417 & .412 & .61551 \\
\hline
\end{tabular}

a. Predictors: (Constant), Accounting information system

Table 7 displays the ANOVA results which test if a model is significantly better at predicting the outcome than using mean. The F-Test for regression model is 72.337 with a significant value of $.000(p=.000<0.05)$ which shows that the model which shows that a model is a good fit for predicting the outcome of the variable. This follows the rule of thumb which states that the model is significant if the value of F-test is greater or equal to 2 Soyinka et al., (2017). However, Field (2009) argue that the model is significant if the value of F-test is greater than 1. 
Victoria Lucas Mkonya, Yu Jintian, Stella Binauli Nanthuru, Salimu Abushiri Jinyevu

Analysis of Top Management Support and Individual Factors Influence on Accounting Information System and Its Impact on the Accounting Information Quality for Projects

Table 7: ANOVA $^{\mathrm{a}}$

\begin{tabular}{|l|l|r|r|r|r|r|}
\hline \multicolumn{2}{|l|}{ Model } & Sum of Squares & df & Mean Square & F & \multicolumn{1}{c|}{ Sig. } \\
\hline \multirow{4}{*}{1} & Regression & 27.405 & 1 & 27.405 & 72.337 & $.000^{\mathrm{b}}$ \\
\cline { 2 - 8 } & Residual & 38.264 & 101 & .379 & & \\
\cline { 2 - 8 } & Total & 65.669 & 102 & & & \\
\hline
\end{tabular}

a. Dependent Variable: Accounting information quality (AIQ)

b. Predictors: (Constant), Accounting information system (AIS)

Coefficient Table 8 explains the importance of independent variable accounting information system in predicting dependent variable accounting information quality. The value of unstandardized (B) coefficient explains the relationship between dependent variable (accounting information quality) and independent variable accounting information system (Field 2009). The results indicate that for every increase in the use of accounting information system result to the increase in accounting information quality by 0.589 . The $t$ value of accounting information system is 8.505 at $p<0.05$ this means that accounting information system is a significant predictor of accounting information quality. The standardized beta coefficient of accounting information system is 0.646 at $\mathrm{p}<0.05$ which means accounting information system has an impact on the model.

Table 8: Coefficients ${ }^{\mathrm{a}}$

\begin{tabular}{|l|l|r|r|r|r|r|}
\hline \multicolumn{2}{|l|}{ Model } & \multicolumn{2}{|c|}{ Unstandardized Coefficients } & \multicolumn{1}{|c|}{$\begin{array}{c}\text { Standardized } \\
\text { Coefficients }\end{array}$} & \multirow{2}{*}{ Sig. } & \\
\cline { 3 - 7 } \multicolumn{2}{|c|}{} & \multicolumn{1}{|c|}{ B } & Std. Error & Beta & & \\
\hline \multirow{2}{*}{1} & (Constant) & 1.237 & .251 & & 4.924 & .000 \\
\cline { 2 - 7 } & AIS & .589 & .069 & .646 & 8.505 & .000 \\
\hline
\end{tabular}

a. Dependent Variable: Accounting information quality

\subsection{Discussion}

The findings of the study revealed top management support and individual factors are both significant predictors of accounting information system. The results are supported by a review of the literature on top management supports and individual factors influence on accounting information systems (Komala 2012; Daoud and Triki 2013). The statistical results indicate that accounting information system is significantly influenced by top management support with a p-value of 0.000 which is less than $0.05(\mathrm{p}=.000<0.05)$ at $\mathrm{t}$ value of 6.085 and individual factors significantly affect accounting information system with a $\mathrm{p}$-value of 0.000 which is less than $0.05(\mathrm{p}=.000<0.05)$ at $\mathrm{t}$ value of 5.854. The correlation between top management support and individual factor to accounting information system shows there strong positive correlation between top management support, individual factor and accounting information system of .760.

The contribution of top management support and individual factor to accounting information system of the nongovernmental organization projects in Tanzania is $57.7 \%$, and the rest are attributed to other factors. This means top management's support is vital in the organization in formulating policy, procedures, and supervision on accounting information system which are used to protect organization assets from loss or frauds, to ensure accuracy and reliability of accounting records and reports. Knowledge, experience of users, management and information system person in charge contribute to successful accounting information system in the organization.

AIQ is significantly impacted by AIS with a p-value of 0.000 which is less than $0.05(\mathrm{p}=.000<0.05)$ at $\mathrm{t}$ value of 8.505 . These findings concur with the result of kanakriyah (2016) on examining the effect of accounting information system on accounting information quality. The correlation between accounting information system and accounting information quality is 0.646 which is positive. Accounting information system contributes to $41.7 \%$ of accounting information quality. Generally accounting information system has an impact on the quality of report through its activity of collecting, recording, processing and reporting. For managers, apart from its function of recording, processing, and reporting, accounting information system can assist in control, help managers and other staff to analyze problems through the information produced and create a new way to achieve their objectives(Laudon and Laudon 2012). 


\section{Conclusion}

The development of information technology leads to the use of accounting information system in managing and reporting financial resources for projects. Accounting records are transported from paperwork to sophisticated accounting information systems which collect, records, store and process data to produce information. The implementation of accounting information system viewed to require the support from top management and individual factors. The research examined the effect of top management support and individual factors on the implementation of accounting information system and its impact on quality of accounting information for nongovernmental organizations projects in Tanzania. The theoretical foundation and review of literature deemed relevant to the study were reviewed. The study variables tested are top management support, individual factors, accounting information system and accounting information quality. The study population included accounting information users (accountants, investors, auditors, and project managers) and who use accounting software for projects. The study uses Statistical Package for Social Sciences for data analysis. The results indicate that top management support and individual factors significantly influence accounting information system. There is positive correlation between top management support, individual factor and accounting information system. The accounting information quality is significantly influenced by accounting information system and the correlation between accounting information system, and accounting information quality is positive. A contribution of top management support and individual factors to accounting information system and of accounting information system to accounting information quality was identified. The research found that accounting information system can be enhanced by top management support and individual factor and accounting information quality by accounting information system. Furthermore, the study contributes to an understating of accounting information system in producing quality accounting information. These findings can be used to solve problems that hinder the implementation of accounting information systems for attaining quality information in nongovernmental organizations projects in Tanzania.

\section{Acknowledgment}

We would like to acknowledge the advice and contribution of Professor Yu Jintian of the School of Management, Wuhan University of Technology, Wuhan P. R. China

\section{References}

- Abdallah, A.A.J. (2014). The impact Of Using Accounting Information Systems On The Quality Of Financial Statements Submitted To The Income And Sales Tax Department In Jordan. European Scientific Journal, ESJ, 9(10), 41-48.

- Al-Ammary, J. and Hamad, S. (2012), Information Technology for Enhancing NGOS' Performance In The Kingdom of Bahrain. International Journal of Electronic Commerce Studies, 3(1), 111-120.

- Aziz N.M, Salleh H, and Mustafa N.K.(2012),People Critical Success Factors (CSFs) in Information Technology/Information System (IT/IS) Implementation. Journal of Design and Built, 5(1), 1-17

- Baccarini, D. (1999), The Logical Framework Method for Defining Project Success. Project Management Journal, 30(4), 25-32.

- Bamber, M. and Cheema, S. (1990), Case Studies of Projects Sustainability: Implications for Policy and Operations from Asian Experience. Washington DC. The World Bank. Crossref

- Betts, S.C. (2003). Contingency theory: Science or technology. Journal of Business and Economics Research, 1(8), 123-130.

- Daoud, H. and Triki, M.(2013). Accounting Information Systems in an ERP Environment and Tunisian Firm Performance. The International Journal of Digital Accounting Research, 13, 1-35 Crossref.

- Elonen, S. and Artto, K.A. (2003). Problems in Managing Internal Development Projects in Multi-Project Environments. International Journal of Project Management, 21(6), 395-402 Crossref.

- Field, A.P. (2009). Discovering statistics using SPSS: and sex and drugs and rock' "n'roll. 3 rd Edition. London: Sage.

- Gelinas, U and Dull, B. R.(2012). Accounting Information System, Ninth Edition. South Western Cengage Learning. 5191. Natorp Boulevard Mason, USA.

- Ginzberg, M. J. (1980). An Organizational Contingencies View of Accounting and Information Systems Implementation. Accounting, Organizations and Society, 5(4), 369-382 Crossref.

- Hall, J A.(2011). Accounting Information Systems. Seven editions, Mason-USA: South-Western Cengage Learning. 
- Hyvari, I. (2006). Success of Projects in Different Organizational Conditions . Project Management Journal, 37(4), 31-42.

- Ihemeje, J.C., Okereafor, G., Ogungbangbe, B.M., and Okpara, M. (2015). The Use of Accounting System in the Nonprofit-Oriented Church Organizations of Nigeria. International Journal of Management Science and Business Administration, 1(12), 58-66 Crossref.

- Ika, L. A .(2012). Project Management for Development in Africa: Why Projects are Failing and What Can be Done About It. Project Management Journal, 43(4), 27-41 Crossref

- Ika, L.A., and Lytvynov, V. (2011). The "Management-Per-Result" Approach to International Development Project Design. Project Management Journal, 42(4), 87-104 Crossref.

- Iskandar, D. (2015). Analysis of Factors Affecting the Success of the Application of Accounting Information System. International Journal of Scientific \& Technology Research, 4(2), 155-162.

- Junglas, I., Abraham, C., and Watson, R. T. (2008). Task-Technology Fit for Mobile Locatable Information Systems. Decision Support Systems, 45(4), 1046-1057 Crossref.

- Kanakriyah, R.(2016). The Effect of using Accounting Information Systems on the Quality of Accounting Information According to users Perspective in Jordan. European Journal of Accounting, Auditing and Finance Research, 4(11), 58-75.

- Kanellis, P., Lycett, M., and Paul, R. J. (1999). Evaluating business information systems fit: From concept to practical application. European Journal of Information Systems, 8(1), 65-76 Crossref.

- Komala A.R. (2012). The Influence of the Accounting Managers' Knowledge and the Top Managements' Support on the Accounting Information System and its Impact on the Quality of Accounting Information: A Case of Zakat Institutions in Bandung. Journal of Global Management, 4(1), 53-73.

- Kuen, C.W, Zailani, S. and Fernando, Y. (2009). Critical Factors Influencing the Project Success amongst Manufacturing Companies in Malaysia. African Journal of Business Management, 3(1), 016-027.

- Laudon, K. C. and Laudon J P.(2012). Management Information Systems.Managing. The Digital Firm. 12th Edition, Pearson Education Inc. Upper Saddle River, New Jersey, 07458

- Lippert, S. K., and Forman, H. (2006). A Supply Chain Study of Technology Trust And Antecedents to Technology Internalization Consequences. International Journal of Physical Distribution and Logistics Management, 36(4), 270 288 Crossref.

- Mahmood, M.A., and Swanberg, D.L. (2001). Factors Affecting Information Technology Usage: A Meta-Analysis of Empirical Literature. Journal of Organizational Computing and Electronic Commerce, 11(2), 107-130 Crossref.

- McLeod, R. and Schell, G.P. (2008). Management Information Systems, Tenth Edition, Upper Saddle River New Jersey 07458: Pearson/Prentice Hall.

- Nelson, R. R., Todd, P. A., and Wixom, B. H. (2005). Antecedents of Information and System Quality: An Empirical Examination within the Context of Data Warehousing. Journal of Management Information System, 21(4), 199-235 Crossref.

- Nicolaou, A.I. (2000). A contingency model of perceived effectiveness in accounting information systems, Organizational coordination and control effects. International Journal of Accounting Information Systems, 1(2) 91 105 Crossref.

- O’Dwyer, B., and Unerman, J.(2010). Enhancing the role of accountability in promoting the rights of beneficiaries of development NGOs. Journal of Accounting and Business Research, 40(5), 451-471 Crossref.

- Otley, D. T.(1980). The Contingency Theory of Management Accounting: Achievement and Prognosis. Accounting, Organizations and Society, 5(4), 413-428 Crossref.

- Reinking J. (2012). Contingency Theory in Information System Research. In Y.K. Dwivedi et al. (eds.), Information Systems Theory. Explaining and Predicting Our Digital Society, Vol. 1, Integrated Series in Information Systems 28, pp.247-262 Crossref.

- Romney M. B. and Steinbart, P J.(2012). Accounting Information System. Global Edition, Twelfth Edition, England: Pearson Education Limited.

- Sajady H, Dastgir M, Hashem H.(2008). Evaluation of the Effectiveness of Accounting Information Systems. International Journal of Information Science and Technology, 6(2), 49-59.

- Schipper, K and Linda V. (2003). Earnings Quality. Accounting Horizons, 17(Supplement) 97-110 Crossref.

- Schmitz HP, Raggo P, Bruno-van Vijfeijken T. (2012). Accountability of Transnational NGOs: Aspirations vs. Practice. Nonprofit and Voluntary Sector Quarterly, 41(6), 1175-1194 Crossref. 
- Shareia B. (2006). The Role of Accounting Systems in Decision Making, Planning and Control in a Developing Country: The Case of Libya. Phd Dissertation, University of Wollongong.

- Soyinka K.A, Fagbayimu M.O, Adegoroye E. and Ogunmola J.O. "Decision Usefulness and Financial Reporting : The General Public Perspective," International Journal of Academic Research in Accounting, Finance and Management Sciences 7(4), 160-168, 2017.

- Spiceland J.D, Wayne Thomas, W. and Herrmann D. (2011), Financial Accounting. 2nd Edition, McGraw-Hill/Irwin,

- Szewczak E. and Snodgrass C. (2002). Human factors in information systems. Hershey, PA: IRM Press.

- Tambovcevs, A. (2010). ERP System Implementation: A Case Study of the Construction Enterprise. Economics and Management, 15, 1092-1098.

- Wu, J.H., Chen, Y. C., and Lin, L. M. (2007). Empirical Evaluation of the Revised End User Computing Acceptance Model. Computers in Human Behavior, 23 (1), 162-174 Crossref.

- Xu, H (2003). Critical Success Factors for Accounting Information Systems Data Quality. Phd Thesis, University of Southern Queensland.

- Young, R. and Jordan, E.(2009). Top Management support: Mantra or necessity?. International Journal of Project Management, 26(7), 713-725 Crossref.

- Zwikael, O. (2008). Top Management Involvement in Project Management; A Cross Country Study of the Software Industry. International Journal of Managing Projects in Business, 1(4), 498-511 Crossref. 